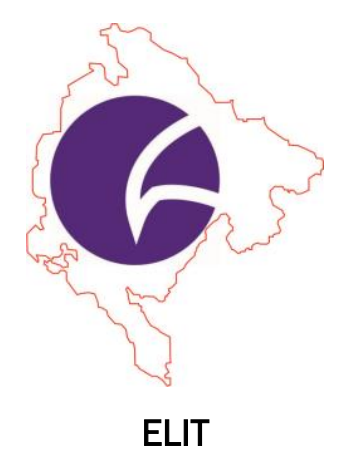

Economic Laboratory Transition Research Podgorica

\section{Montenegrin Journal of Economics}

Alimbaev, A., Bitenova, B., Bayandin, M. (2021), “Information and Communication Technologies in the Healthcare System of the Republic of Kazakhstan: Economic Efficiency and Development Prospects", Montenegrin Journal of Economics, Vol. 17, No. 3, pp. 145-156.

\title{
Information and Communication Technologies in the Healthcare tem of the Republic of Kazakhstan: Economic Efficiency and Development Prospects
}

\author{
ABILDA ALIMBAEV ${ }^{1}$, BAGDAT BITENOVA ${ }^{2}$ and MARAT BAYANDIN³
}

\footnotetext{
1 Professor, Doctor of Economic sciences of Karaganda Economic University of Kazpotrebsoyuz, Director of the Research Institute for Regional Development, Karaganda, Kazakhstan, e-mail: abilda.alimbayev@mail.ru ORCID: 0000-0002-3112-8053; Scopus Author ID: 57208009784

$2 \mathrm{PhD}$ student of Karaganda Economic University of Kazpotrebsoyuz, Karaganda, Kazakhstan, e-mail: bagdat_1987@mail.ru; ORCID 0000-0003-0865-3113

3 Professor, Doctor of Economic sciences of Kostanay Engineering and Economics University named after M.Dulatov, Kostanay, Kazakhstan, e-mail: mbayandin.71@mail.ru; ORCID: 0000-0002-2158-4370; Scopus Author ID: 57192591552
}

\section{ARTICLE INFO}

Received October 08, 2020

Revised from November 12, 2020

Accepted December 11, 2020

Available online September 15, 2021

JEL classification: 014, 047, P46, H51

DOI: $10.14254 / 1800-5845 / 2021.17-3.12$

\section{Keywords:}

Information and communication technologies,

e-health,

economic models,

digitalization,

economic development.

\begin{abstract}
The article examines the impact of information and communication technologies development in health care on economic growth. The main indicator of the author's economic growth is gross value added. The aim of the study is to identify a quantitative assessment of the impact of ICT costs on the gross value added (GVA) of healthcare in the Republic of Kazakhstan, as well as an analysis of the state of e-health in the Republic of Kazakhstan, a SWOT analysis of the healthcare system in the aspect of a unified information system. The methodology is based on a quantitative assessment of the impact of ICT costs on increasing the GVA of healthcare in the Republic of Kazakhstan. The tools of economic and mathematical modeling were used as the main method for modeling the links between ICT and social services and the growth of gross value added. Research based on data from official statistics for the Republic of Kazakhstan for the period 2010-2018. Based on this model, it was concluded that spending on ICT development has a positive effect on the GVA of health care. Based on the global trends in innovative development, it can be concluded that today Kazakhstan needs to ensure the further development of ICT.
\end{abstract}

\section{INTRODUCTION}

Recent economic studies in the theory of evolutionary and endogenous growth indicate that knowledge and technology play a decisive role in the development of economic systems. The process of 
digital transformation of the economy to a large extent determines the effectiveness of economic development. Its competitiveness in the context of globalization and international integration is largely determined by the accumulated and implemented human capital in the country. As you know, the leading countries of the world have achieved success in the field of scientific and technological progress due to the intensive development of education, science and health.

Analysis of the current state and development trends of e-health and the developed SWOT analysis not only explain the existing imbalances, but also predict their further development. This problem is of particular relevance for Kazakhstan, whose economy largely depends on the extraction and sale of minerals, and the share of high technology is low. The urgent task of the transition from a commodity economy to innovative development is to increase competitiveness through the use of advanced technologies, which requires the qualitative development of new types of capital - human and social. At the same time, Kazakhstan has innovative potential, expressed in the high level of the educated population, in a high proportion of highly qualified specialists, as well as resources for the implementation of the Digital Kazakhstan program. However, the insufficient scale of ICT implementation in the regions, as well as the lack of production of ICT equipment, in almost all regions of the Republic, inhibits the effectiveness of innovation policy.

The spread of the main trends of the industry 4.0 global revolution and the increasing competition in world markets in the 21st century have contributed to strengthening the strategic position of any country in the long term. According to the World Economic Forum, digitalization has great potential for business and society and can bring an additional 30 trillion dollars of revenue for the global economy over the next 10 years. From the point of view of applicability to Kazakhstan, models and methods of studying the problems of using ICT and its relationship with economic growth are of greatest interest. Therefore, it is relevant to justify the choice of a common paradigm for modeling the relationship between ICT spending and economic growth. By the mean number of employees, SMEs are divided into three categories of medium-sized (101 to 250 persons), small (15 to 100 persons), and micro (15 persons and fewer) (Official website of the President of Russia, 2020). The annual limits of business income for each category of SMEs are 2 billion, 800 million, and 120 million rubles, respectively (Official website of the Government of the Russian Federation, 2020). In Russia, there are 5.979.899 small and medium-sized organizations, of which 16.978 are medium-sized businesses, 222.144 are small businesses, and 5.740 .777 micro companies (Unified Register of Small and Medium-Sized Business Entities of the Russian Federation, 2020).

\section{LITERATURE REVIEW}

In conduction of this research the study of penetration of information and communication technologies in the sectors, which contribute to the growth of the efficiency and competitiveness of the economy, is of great importance. The mechanism of widespread use of ICTs is based on the process of transferring data, information and knowledge, the exchange of scientific and engineering thoughts, as well as messages on the results obtained in undertaken studies. Economists began to approach the study of the mechanisms of dissemination of innovative processes similar to the physical phenomenon of distribution in various environments in the middle of the last century. The spatial system necessarily evolves along with the distribution processes. This is evidenced by numerous basic research. Innovations are distributed through market and non-market channels, from the place of their first sale to various consumers, countries, territories, industries, markets and enterprises (OECD, 2018). Without the widespread dissemination and implementation of innovations, it makes no economic sense.

Part of the mechanism for spreading and introducing innovations are channels - ways of penetrating innovations. They can be divided into interpersonal (transferring information from person to person directly) and special or remote (iconic and technical means of transmitting information). Nowadays, ICT is the locomotive tool of accelerated development in many areas of the economy. It has become fashionable to talk about new technologies in the digital and electronic economies. These concepts are used interchangeably and mean almost the same thing. In the near future, the digital economy may become a new tool that will open up great opportunities for all spheres of life, so it is very important to understand how to digitalize various structural elements (Satpaeva and Kalymbekova, 2019). Radical changes in 
most industries happen under the influence of such global trends as the emergence of breakthrough technologies, digitalization, and acceleration of the product life cycle. Progress toward a greener and more competitive economy is possible only if all components of social security are accounted for by firms, stakeholders, and policymakers. It is well known that sustained economic growth depends on sustained investment in technological, organizational, and new ways of managing production (Veselovsky, Izmailova, Lobacheva, Pilipenko and Rybina 2019).

Digital technologies allow enterprise management and individuals to reduce transaction costs of interaction on an ever-increasing scale and make closer contact with business entities and government agencies (TETIDT, 2019). As a result, an economy based on network services is formed, i.e. digital or electronic (Cardona, Kretschmer and Strobel, 2013;Panshin, 2017). Thus, Negroponte (1995), ab American computer scientist, presented the electronic economy as a transition from the movement of atoms to the movement of bits. This concept is associated with the intensive development of ICT and the beginning of the process of digitalization of society, which is based on the fourth industrial revolution.

In many countries, programs exist to support the adoption and use of ICT. However, there is a growing trend, in both developed and developing countries, to establish barriers to Internet access, which could threaten the fundamental right to freedom of expression and weaken the Information Society, which favors the expansion of capabilities so that people can lead the life they really want. It is therefore essential that public policies in each country and international agreements continue to defend free and secure access to the Internet as the main means of global communication and information provision (de la Hoz-Rosales, Camacho-Ballesta and Tamayo-Torres, 2019). The introduction of ICT allows to develop and raise the economy not only of large cities, but also of small villages, providing them with access to information and expanding the quantity and quality of social services (Zolfani, Sedaghat and Zavadskas, 2012). Formation of the basic model of this study corresponds to the traditional models of catching up endogenous growth. This model was basically formulated back in the 30s of the last century by a Japanese economist K. Akamatsu (1962). In subsequent years, the basic principles of the theory of "goose wedge" were further developed in the scientific concept of "accelerated catching up" development.

One of its ideologists, J. Sachs (2005), defines the process of catching up development as a process in which an economy with a lower level of technology and income reduces the gap with economies with more advanced technologies and a higher level of welfare by using innovation and the flow of capital from a "leader" to a "follower". Accelerated reindustrialization, modernization, involving the use of information and operational technologies, efficient energy sources, deepening the division of labor, and the development of the commodity and money markets, are the fundamental core of the catch-up development of the economy. This theory has recently received a rigorous mathematical justification thanks to the work of D.L. Anselin, D.Audres and M.F. Feldman (1997, 1996). P. Romer (1986) theoretically substantiated the influence of endogenous factors on economic growth. His calculations contain generalizations of localized effects that positively affect innovation.

A number of Russian scientists study the impact of information and communication technologies on various sectors of the economy, with particular attention being paid to sectors such as health, education and science (Leonov, 2018; Korobkova, 2018). New technologies are the most visible sign of changes in economic systems, and they are often called the driver of economic development. The main idea of such reasoning is that the increased volume of technological innovations in the field of data processing and transferring leads to a reorganization of socio-economic relations, since their impact is quite significant. Many researchers in their works note the importance of the influence of technological innovations. The spread of digital technologies gives rise to discussion about the formation of new socio-economic relations, the digital economy (Semenov, 2017). Each country has its own specific features that determine the general model of the digital economy, the development of information infrastructure, the creation and application of information and communication technologies and the mechanisms for their implementation(Molinari and Torres, 2018). These features are of a different nature, but new economic relations are gradually forming, and the economy is becoming more integrated in the world community, there is an urgent need for structural changes and closer interaction between the state and the private sector.

An effective structure such as public-private partnership (PPPs) has evolved and is playing an increasingly important role. The increased interest in this interaction between the state and business is 
explained by the fact that in many countries the pooling of resources from the public and private sectors can effectively solve major social and economic problems and develop their information infrastructures. Most PPPs are focused on basic directions, defining development goals and objectives: a) key institutions within which conditions for the development of the digital economy (statutory regulation, personnel and education, the formation of research competencies and technology departments) are created; b) basic infrastructural elements of the digital economy (information infrastructure, information security). In world practice, there are many successful examples of public-private partnerships that can be seen in the works of such scientists as I.A. Nikonova, I.Z. Yarygina (2018), V.N. Mochalyshkov (2012). This topic is of particular relevance for socially significant areas, in particular for the healthcare sector - medicine. Serious changes are needed in the management of medical institutions, pursuing the goal of developing new approaches, methods and forms of work for organizations, and adjusting the system of relations with a constantly changing external environment. The development of medical technologies significantly increases the ability to really influence the health indicators of the population, as evidenced by the significant successes in the fight against the most life-threatening diseases achieved in developed countries. To improve the health situation of citizens, it is necessary to ensure a qualitative breakthrough in the healthcare system. The industry needs innovative developments in the field of prevention, diagnosis and treatment of diseases (including rehabilitation), an effective system for the training and retraining of medical personnel, and modern high-tech information systems. It is noted that one of the most important tasks is the informatization of the healthcare system, including the introduction of electronic document management in medical organizations and the creation of a medical information and educational resource (Borkova, Napolova and Orlov , 2019).

Since 2009, the International Telecommunication Union (ITU) is annually publishing the "Measuring the Information Society" report, which presents the development of ICT, evaluating country results regarding ICT infrastructure and skills, as well as the ICT price basket index, which tracks and compares the cost and availability of ICT. According to the latest ITU report on the ICT Development Index 2018, Kazakhstan is ranked 52nd (Figure 1). The first three places in the ranking were taken by South Korea, Spain and Denmark. Among the CIS countries, Belarus occupies the leading position (31st place), followed by Russia (42nd place), Kazakhstan (52nd place), Moldova (68th place) (ITU, 2017). Currently, investment in the ICT sector is becoming a priority for many countries. Numerous studies and successful international experience have proved that a developed sector of information technology (IT) contributes to the growth of efficiency and competitiveness of the economy (Burkov, 2013). South Korea is a classic example of such effects, as over the period from 1999 to 2003, the information technology sector grew by $43 \%$. For comparison, we note that over the same period in Singapore the growth rate was 5\%, in Malaysia - less than 1\%. The success of South Korea is explained by the fact that the development of the ICT sector was put in a national priority, which, in turn, required significant subsidies from the state. These actions led to the fact that the ICT sector has become the largest segment of the national economy, which accounts for $17 \%$ of the country's gross national product and $43 \%$ of all South Korean exports (Beardsley et al., 2010).

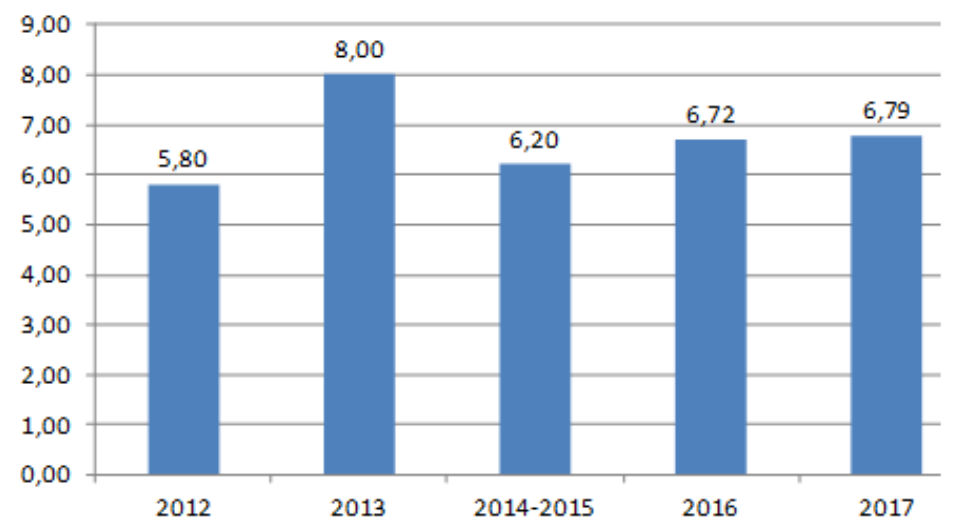

Figure 1. Dynamics of change of indicators of the Republic of Kazakhstan on development of ICT

Source: International Telecommunication union, ICT Development Index 2017 
The uniqueness of the current situation is that about 5.5\% of world GDP falls on the ICT sector, and according to the forecasts of the McKinsey consulting company, this figure will reach around $9 \%$ by 2020 (McKinsey \& Company, 2011). This suggests that ICT is becoming a serious factor in the growth of GDP in the global economy. Nowadays, even in countries that have entered the post-industrial period of economic development, information technology continues to be the backbone of the economy. The fact is that in addition to the economic aspect, the ICT sector has the exceptional ability to build more stable relationships. According to the results of recent studies of consumer markets by McKinsey consulting company, it is argued that ICT is one of the four leading areas of economic activity in terms of intensity of influence on modern society, following healthcare, agriculture and utilities. Figure 2 shows the industries that have the greatest impact on social development (Qiang, Rossotto and Kuniko, 2009).

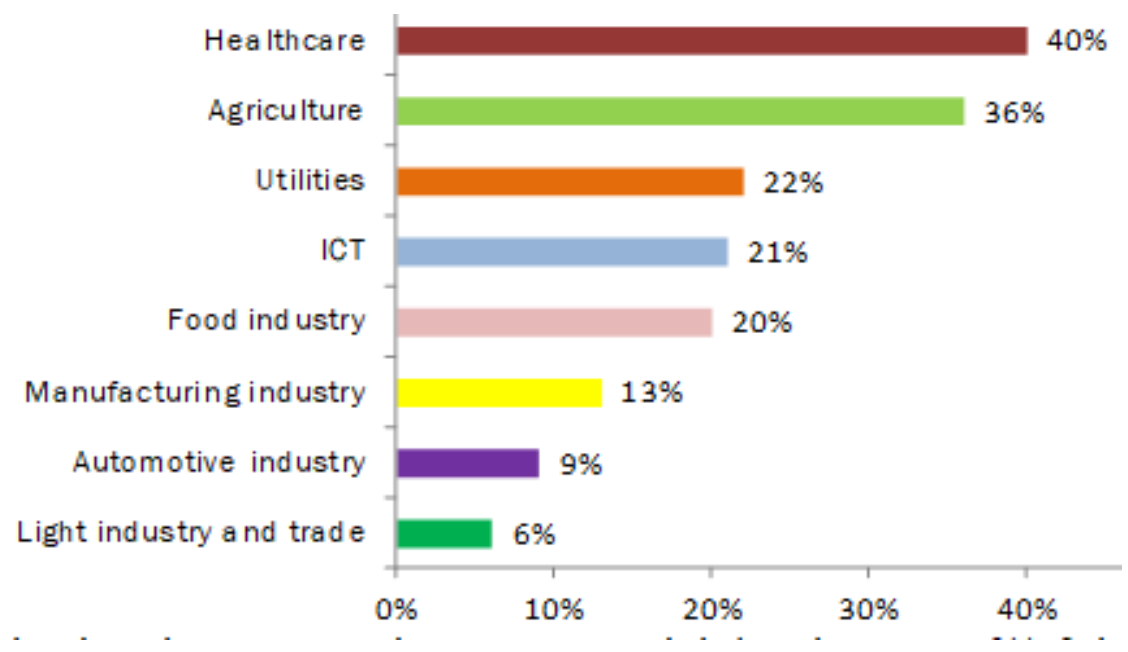

Figure 2. Sectors having the greatest impact on social development, \%(of the number of consumers surveyed)

Source: Qiang et al., 2009.

The use of modern ICT in healthcare is caused by large volumes of information, methods of its collecting, processing and transferring. The process of informatization of healthcare in the Republic of Kazakhstan is gaining momentum every year. Therefore, the appearance in the speeches of President $\mathrm{K}$. Tokayev that the digital economy will determine the future and, in fact, is the locomotive of the country's development. In this regard, the introduction and widespread use of modern ICT and the development of telemedicine are aimed at rationalizing the work of medical workers, ensuring accessibility and improving the quality of medical care, which determines the relevance of the study.

\section{METHODOLOGY}

Information technology, which today is a component of fixed capital, allows, on the one hand, to facilitate work by replacing the physical energy of a person and increasing labor productivity. On the other hand, the share of fixed capital in the value of the produced product or service is growing per worker (capital-labor ratio). As the capital-labor ratio of labor grows, so does the qualification of workers, since information technology contributes to the development of the intellectual abilities of specialists. Therefore, in the aggregate, labor and fixed capital will increase the volume of sales of goods and services (hereinafter the volume of production), while improving the quality of the manufactured products or services, in our case, the quality of medical care and saving time, without much stress. As a result, a person has more free time. This result corresponds to the universal economic law of saving time, expressing the source and method of increasing social reproduction.

The Law of time saving was formulated by K. Marx (1959) in connection with the identification of the historically passing significance of money as a cost form of manifestation of society, the nature of production. The essence of this law is to eliminate the contradiction between the need to increase free time 
and busy time. Saving of busy time and increasing free time are components of social progress. Today, the countries that have high results of scientific and technological progress, a high level of culture of the population, and a high level of medical care mainly achieve this due to the increase in free time due to the saving of busy time.

For empirical testing of the studied problem, the authors put forward a hypothesis: it is assumed that ICT indicators have a statistically significant and positive effect on economic growth. In accordance with theoretical approaches to the study of innovation, they activate the process of creating gross value added. To calculate the model, the annual data of The Ministry of National Economy of the Republic of Kazakhstan Statistics Committee for 2010 - 2018 time period were used. The economic result of the health sector, like any other sector, is the gross value added indicator, which is measured in the system of national accounts. The gross value added indicator is influenced by many factors, the combined effect of which can be correctly taken into account on the basis of the correlation-regression model.

One of the methods that allows to investigate the dependence of one variable on several explanatory factor variables influencing it is multiple regression analysis. For this, the multiple linear regression equation is constructed

$$
y=a+b_{1} x_{1}+\ldots+b_{k} x_{k}
$$

The parameters $b_{i},(j=\overline{1, k})$ of a quantitative explanatory variable are interpreted as the average change in the resulting variable with a single change in the explanatory variable itself and the constant values of the remaining independent variables. The free term $a$ determines the value $y$ at zero values of all factor variables. The parameters of the multiple regression equation are estimated using the least squares method. When applied, a system of normal equations is constructed, the solution of which allows one to obtain estimates of the regression parameters (Yemelina, 2015). The results of calculations using this model will allow us to characterize the quantitative relationship between gross value added and the costs of digitalization of healthcare. In the applied model, the gross value added of healthcare acts as a dependent variable and the dependence on various factors is estimated. The following indicators were selected for inclusion in the model (Table 1):

$Y$ (dependent variable) - gross value added (healthcare and social services), mln.tenge

X1 - The volume of services rendered in the field of healthcare and the provision of social services in the Republic of Kazakhstan, million tenge

$X 2$ - Costs of ICT in the healthcare sector, million tenge

X3 - Public expenditures on health care, million tenge

X4 - Private health spending, million tenge

To select the factors that should be included in the multiple linear regression equation, we will use the statistical data of these indicators for the period from 2010 to 2018 (Table 1). Due to the fact that while evaluating multiple linear regression, to ensure statistical reliability of the results, it is required that the number of observations is at least 3 times higher than the number estimated by the parameter, only two factors can be included in the desired model.

Table 1. The source data for 2010 - 2018 in the context of the analyzed parameters

\begin{tabular}{|c|c|c|c|c|c|}
\hline Years & $Y$ & $X 1$ & $X 2$ & $X 3$ & $X 4$ \\
\hline 2010 & 377936,90 & 440284,60 & 1917,99 & 402277,14 & 198077,50 \\
\hline 2011 & 482072,00 & 573801,80 & 2998,5 & 653422,92 & 296992,90 \\
\hline 2012 & 516554,10 & 699390,00 & 4027,67 & 770226,95 & 384354,90 \\
\hline 2013 & 577127,00 & 720519,20 & 5281,98 & 825200,46 & 447510,90 \\
\hline 2014 & 666308,40 & 816427,10 & 4036,1 & 892844,87 & 532092,90 \\
\hline 2015 & 729986,80 & 892643,80 & 5066,9 & 898512,67 & 578957,00 \\
\hline 2016 & 888829,70 & 1082797,40 & 22190,9 & 948038,39 & 645618,10 \\
\hline 2017 & 1075543,50 & 1165626,90 & 9284,5 & 1023872,76 & 626874,60 \\
\hline 2018 & 1172754,30 & 1238640,32 & 17963,1 & 1085236,00 & 679520,60 \\
\hline
\end{tabular}

Source: compiled by the author according to The Ministry of National Economy of the Republic of Kazakhstan Statistics Committee and National Health Accounts 
Further, to build the model, the Microsoft Office application package was used, which made it possible to obtain a correlation matrix. Table 2 presents the correlation matrix, which allows to see a list of factors that directly affect $Y$ and exclude those that cannot be used further to build an econometric model of the analyzed set of parameters.

Table 2. Correlation Matrix

\begin{tabular}{|c|c|c|c|c|c|}
\hline & $Y$ & $X 1$ & $X 2$ & $X 3$ & $X 4$ \\
\hline$Y$ & 1,0000 & & & & \\
\hline$X 1$ & 0,9830 & 1,0000 & & & \\
\hline$X 2$ & 0,7654 & 0,6871 & 1,0000 & & \\
\hline$X 3$ & 0,8894 & 0,9379 & 0,6522 & 1,0000 & \\
\hline$X 4$ & 0,9090 & 0,9611 & 0,7417 & 0,9654 & 1,0000 \\
\hline
\end{tabular}

Source: Author calculated from research data

Table 3. A qualitative interpretation of the theoretical correlation based on the Cheddock scale

\begin{tabular}{|c|c|c|c|c|c|}
\hline $\begin{array}{c}\text { The correlation coefficient by absolute } \\
\text { value }\end{array}$ & $0,1-0,3$ & $0,3-0,5$ & $0,5-0,7$ & $0,7-0,9$ & $0,9-0,99$ \\
\hline Correlation strength characteristic & Weak & Moderate & Observable & High & Very high \\
\hline
\end{tabular}

Source: (Statistics: textbook and workshop for academic undergraduate 2018)

Tables 2 and 3 show that the analyzed $Y$ - "gross value added, mln. tenge" is influenced by factors such as $X 1$ and $X 4$, in which the correlation coefficient exceeds $90 \%$, factorX3is high being more than $80 \%$. The analysis of the values of the correlation matrix shows that GVA $(Y)$ is most affected by the factor "the volume of rendered services in the field of healthcare and the provision of social services" (X1). Since the factor "costs for ICT in the field of health care" (X2) is important for the study, we use it to further build the model. In addition, there is no multicollinear dependence $\left(r_{x_{4} x_{8}}=0,6871<0,7\right)$ between these factors. Therefore, the two factors X1 and X2 must be included in the multiple regression model. Thus, the desired two-factor linear regression equation will have the following form:

$$
y=a+b_{1} x_{1}+b_{2} x_{2}
$$

Since the initial indicator $X 2$ - costs for ICT in the health sector is a subject to fluctuation, we conducted exponential smoothing of this time series (smoothing parameter $\alpha=0,1$ ) in advance. Exponential smoothing is one of the most common techniques used for smoothing time series, as well as for forecasting. The smoothing procedure is based on the calculation of exponential moving averages of the smoothed series (Lukashin, 2003). After that, using the "Data Analysis" add-in, calculations of indicators of the future regression model were carried out (Table 4).

Table 4. Regression statistics

\begin{tabular}{|c|c|}
\hline Parameter & Indicator \\
\hline \multicolumn{2}{|l|}{ Regression statistics } \\
\hline Multiple R & 0,9834 \\
\hline R-suqared & 0,9671 \\
\hline Normalized R-squared (reduced coefficient of determination) & 0,9561 \\
\hline Standard error & 57266,3815 \\
\hline Observations & 9,0000 \\
\hline \multicolumn{2}{|l|}{ Coefficients } \\
\hline Y-intersection & $-92328,5235$ \\
\hline $\begin{array}{l}\text { X1 - The volume of rendered services in the field of healthcare and the provision of } \\
\text { social services in the Republic of Kazakhstan }\end{array}$ & 0,9241 \\
\hline X2- Costs of ICT in the healthcare sector & 4,5744 \\
\hline
\end{tabular}

Source: compiled by the authors 
As a result of approximating the initial statistical data using the "Regression" tool (Data Analysis in Microsoft Office Excel), the following two-factor linear regression equation was obtained:

$$
y=-92328,52+0,92 x_{1}+4,57 x_{2}, \quad R^{2}=0,98
$$

After constructing the multiple linear regression equation, it is necessary to evaluate the quality of the model in the following areas:

a) check of the quality of the regression equation (correlation coefficient, determination coefficient);

b) check of the significance of the regression equation (Fisher criterion).

The multiple correlation coefficient is $\mathrm{R}=0,98$, which indicates a close relationship of the resulting attribute with two factor attributes at the same time. In addition, from the data of the protocol for performing the regression analysis, we have that the observed value of the Fisher criterion is equal $F_{\text {obsrvd. }}=88,21$. The critical value of the Fisher criterion at the significance level of $\alpha=0,05$ and the number of degrees of freedom $k_{1}=m=2, \quad k_{2}=n-m-1=6$ (where $\mathrm{n}$ is the number of observations, $\mathrm{m}$ is the number of factors) is $F_{\text {crit. }}(0,05 ; 2 ; 6)=5,14$. Since $F_{\text {obsvd. }}>F_{\text {crit. }}(88,21>5,14)$, therefore, the obtained regression equation is statistically significant and reliable.

\section{RESULTS AND DISCUSSION}

As a result of the obtained two-factor regression equation analysis, the following conclusion was made:

- with an increase in the volume of rendered health services and the provision of social services by 1 million tenge, GVA increases by 0.92 million tenge;

- an increase in ICT costs in healthcare sector by 1 million tenge entails an increase in GVA by 4.57 million tenge.

According to the Ministry of Health of the Republic of Kazakhstan, today thanks to digitalization, savings of about 315.4 million tenge have been achieved on the purchase of paper for medical paper documentation; the cost of purchasing supplies for medical images (fluorography, x-ray, mammography, etc.) has decreased by 224.7 million tenge; visits to the clinic have been reduced by $8 \%$, as well as live queues decreased by $30 \%$ due to pre-registration through electronic services, the time spent by patients in the clinic before receiving services decreased by 50\%; also, due to electronic services, the time for obtaining laboratory research results was reduced by a factor of 1.7. From the point of view of sustainable and stable growth in the well-being of the population, one of the priorities of the Republic of Kazakhstan is the healthcare industry, which should become a unified, developed, socially oriented system, recognized to ensure the availability, timeliness, quality and continuity of medical care. The main goal of the healthcare sector development of the Republic will be to improve public health and ensure sustainable socio-demographic development.

Today, the rapid development of information and communication services is becoming a key factor that contributes to the inclusion of the Republic of Kazakhstan in global economic processes. In 2013, with the involvement of international experts from the Swiss Institute of Public Health (Swiss Tropical and Public Health Institute), the effectiveness of the e-health introduction in the Republic of Kazakhstan was assessed (The concept of development, 2013). Based on the results of the abovementioned audit, the Concept of e-health development of the Republic of Kazakhstan for 2013-2020 was developed. Table 5 shows the current information systems integrated into the healthcare system, developed and implemented in accordance with the adopted concept.

The aim of the implementation of these information systems was to create an information and technology platform that ensures the rational use of health resources with better delivery of services to the population. A fundamentally new solution is planned to create or modernize records at various levels of 
medical care and a separate centralized implementation of the electronic health passport as a tool to provide support for clinical decision-making and continuity of medical care.

Table 5. Current information systems integrated into the healthcare system of the Republic of Kazakhstan

\begin{tabular}{|c|c|c|c|}
\hline № & Information systems & Code & Comment on the IS content \\
\hline 1 & $\begin{array}{l}\text { Attached population } \\
\text { register }\end{array}$ & APR & $\begin{array}{l}\text { Transfer of data on an individual, information on the attachment of an individual, } \\
\text { structure of districts, personnel on and off the site }\end{array}$ \\
\hline 2 & $\begin{array}{l}\text { Resource manage- } \\
\text { ment system }\end{array}$ & RMS & $\begin{array}{c}\text { Transfer of a list of medical organizations, a list of employees of medical organi- } \\
\text { zations, bed capacity }\end{array}$ \\
\hline 3 & $\begin{array}{c}\text { Automated } \\
\text { information system } \\
\text { "Clinic" } \\
\end{array}$ & $\begin{array}{l}\text { Clinic } \\
\text { AIS }\end{array}$ & $\begin{array}{l}\text { Sending and receiving data (directions, DAS results, information on a static map, } \\
\text { etc.) }\end{array}$ \\
\hline 4 & $\begin{array}{l}\text { Register of pregnant } \\
\text { women and women } \\
\text { of childbearing age }\end{array}$ & RPWCA & $\begin{array}{l}\text { Management of groups of pregnant women and women of childbearing age to } \\
\text { monitor indicators of their health status. Users of the system are ambulatory- } \\
\text { level medical organizations (obstetrician-gynecologists, general practitioners). }\end{array}$ \\
\hline 5 & $\begin{array}{l}\text { The electronic } \\
\text { register of inpatients }\end{array}$ & ERI & $\begin{array}{l}\text { Upon the patient's admission to hospital for hospitalization, after the patient's } \\
\text { treatment and discharge are completed, personal data is entered into the elec- } \\
\text { tronic information system }\end{array}$ \\
\hline 6 & $\begin{array}{l}\text { Health Services } \\
\text { Quality Management } \\
\text { System }\end{array}$ & HSQMS & $\begin{array}{l}\text { Designed for information support of the functions of management, structural } \\
\text { divisions and individual specialists of governing bodies and healthcare organiza- } \\
\text { tions in planning, accounting, analysis and management (organization), as well } \\
\text { as in monitoring the quality of medical services provided. }\end{array}$ \\
\hline 7 & $\begin{array}{l}\text { Hospitalization } \\
\text { bureau }\end{array}$ & HB & $\begin{array}{l}\text { Designed for the effective management of planned hospitalization, the opera- } \\
\text { tional solution of registration issues, accounting, beds booking, free medical care }\end{array}$ \\
\hline 8 & $\begin{array}{l}\text { Drug provision } \\
\text { management system }\end{array}$ & DSMS & $\begin{array}{c}\text { The register contains complete information on all domestic and foreign medi- } \\
\text { cines, medical devices and medical equipment registered in the Republic of } \\
\text { Kazakhstan that are approved for medical use and sale in the Republic of Ka- } \\
\text { zakhstan. }\end{array}$ \\
\hline 9 & $\begin{array}{l}\text { Cancer patients } \\
\text { electronic register }\end{array}$ & CPER & $\begin{array}{l}\text { Designed to keep track of patients in cancer clinics in the Republic of Kazakh- } \\
\text { stan, maintaining and processing information on the volume of medical care } \\
\text { provided to patients with socially significant diseases. }\end{array}$ \\
\hline 10 & $\begin{array}{l}\text { Medical Technology } \\
\text { Management System }\end{array}$ & MTMS & $\begin{array}{l}\text { Designed for automated collection, processing and storage of data on medical } \\
\text { equipment located in healthcare organizations, as well as for automating the } \\
\text { process of generating an application for the purchase of medical equipment, with } \\
\text { the decision of the parties involved on the application, as well as further monitor- } \\
\text { ing of its use in the healthcare organization. }\end{array}$ \\
\hline 11 & $\begin{array}{l}\text { Provision of } \\
\text { medicines }\end{array}$ & PMIS & $\begin{array}{l}\text { A program that allows you to keep a personal record on the free prescriptions for } \\
\text { each patient and doctor in the by medical institutions }\end{array}$ \\
\hline 12 & $\begin{array}{l}\text { Electronic register of } \\
\text { dispensary patients }\end{array}$ & ERDP & $\begin{array}{l}\text { Designed to form a single centralized information database of patients (electron- } \\
\text { ic register) who are on the dispensary records and to determine the need for free } \\
\text { medication on an outpatient basis }\end{array}$ \\
\hline 13 & $\begin{array}{l}\text { Single payment } \\
\text { system }\end{array}$ & PS APP & $\begin{array}{c}\text { Designed to automate the process of payment for a rendered medical care at the } \\
\text { stage of primary health care and consultative and diagnostic care. An additional } \\
\text { purpose of the System is the implementation of settlements between medical } \\
\text { organizations }\end{array}$ \\
\hline
\end{tabular}

Source: Compiled by the author based on the materials of the RSE on REO "Republican Electronic Health Center" of the Ministry of Health of the Republic of Kazakhstan, 2019.

Electronic health passport (EHP) is a centralized system for storing, processing and transferring EHP for all patients in the country, which will store basic information about patients throughout their lives. The communication of various systems and the exchange of data on the health status of patients will be carried out only by transmitting data to and receiving data from the EHP. The data in the EHP system will be managed by the local doctor, general practitioner. The EHP system is the main tool for integrating all other systems. Using a system analysis, we prepared an up-to-date SWOT analysis of the implementation of information systems in healthcare (Table 6). 
Table 6. Analysis of the implementation of information systems in healthcare of the Republic of Kazakhstan

\begin{tabular}{|c|c|}
\hline Strengths & Weaknesses \\
\hline $\begin{array}{l}\text { The “Digital Kazakhstan" state program was developed } \\
\text { The development of ICT and e-health is a priority in Kazakh- } \\
\text { stan } \\
\text { The presence in the Republic of Kazakhstan of a specialized } \\
\text { enterprise established by the Government - Republican Cen- } \\
\text { ter for Electronic Health } \\
\text { A number of IS and web applications have been introduced in } \\
\text { the Republic of Kazakhstan } \\
\text { The systems are designed to operate in a single database and } \\
\text { apply common concepts and standards. } \\
\text { The country has gained experience in the development of } \\
\text { healthcare IS, there are IT companies specialized in the de- } \\
\text { velopment of such systems } \\
\text { The systems have a fairly rich functionality based on the } \\
\text { needs of the Ministry of Health and Social Development } \\
\text { The presence of telemedicine points in rural medical organi- } \\
\text { zations and their widespread use }\end{array}$ & $\begin{array}{l}\text { Launch of multiple IS and web applications without proper } \\
\text { integration violates the principle of a single database } \\
\text { Insufficient level of digital literacy of a certain part of } \\
\text { healthcare workers (especially for aged people) } \\
\text { Lack of a comprehensive training program for users of in- } \\
\text { formation systems }\end{array}$ \\
\hline Opportunities & Threats \\
\hline $\begin{array}{c}\text { Attraction of investments in healthcare sector and the devel- } \\
\text { opment of PPP } \\
\text { The introduction of CSHI in the Republic of Kazakhstan, as a } \\
\text { pillar for the modernization of IS and increased funding } \\
\text { Technology transfer in collaboration with international part- } \\
\text { ners }\end{array}$ & $\begin{array}{l}\text { Lack of qualified IT specialists, project managers, staff turn- } \\
\text { over } \\
\text { Insufficient number of players in the ICT market of e-health } \\
\text { services (monopolization of system development) } \\
\text { Deterioration of the global economic situation and optimiza- } \\
\text { tion of budget expenditures in Kazakhstan }\end{array}$ \\
\hline
\end{tabular}

Source: compiled by the authors

The SWOT analysis leads to the need for new and conceptual approaches to improving healthcare IS. At the same time, the development of informatization of the healthcare industry with the involvement of the private sector and the development of public-private partnership is becoming relevant. PPP can significantly offset the threats identified in the SWOT analysis and use the possibilities of this type of partnership. Despite the considerable variety of forms and directions of PPPs, it is possible to identify the preferred forms of implementation of PPPs in the healthcare sector (Figure 3).

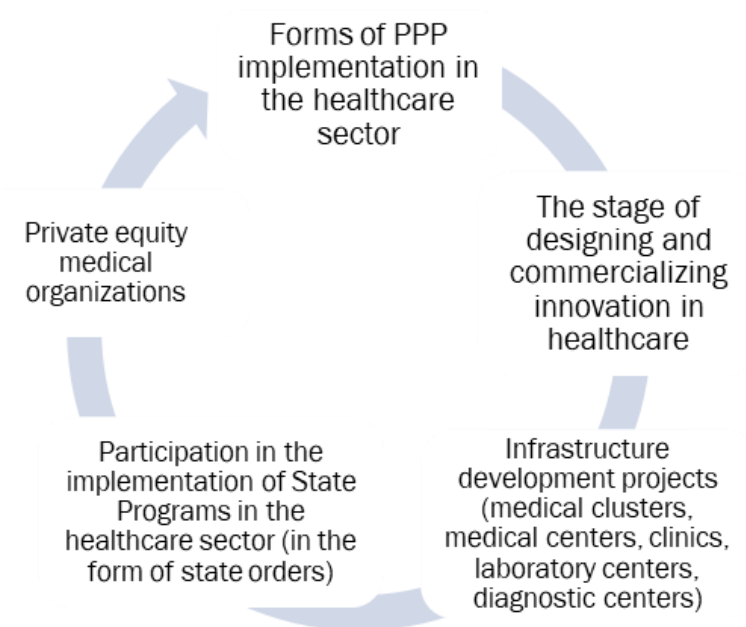

Figure 3. Forms of implementation of PPP depending on the stages of innovation

Source: compiled by the authors

The proposed form of PPP in healthcare is indicative for Kazakhstan in that it reflects current trends, such as:

- Use of combined sources of financing for the modernization of healthcare; 
- Creation of preferential conditions for investors, including long terms for the transfer of new innovations into operation, grace periods for investing;

- Focus not only on national capital investments, but the creation of favorable conditions for the development of foreign business, attracting a great number of investors from all over the world.

\section{CONCLUSION}

Based on global trends in innovative development, we can conclude that today the further development of ICT is required in Kazakhstan. The study confirms the basic theoretical position that the use of ICT is an important factor that can affect the growth of value added in the health system. At the same time, methods for assessing the relationship between the use of ICTs and health care costs expand analytical capabilities and identify ways and reserves to increase the use of ICT.

The development of ICT, including in the health sector, is a priority strategic direction. However, ehealth is developing through centralization, where the Ministry of Healthcare of the Republic of Kazakhstan plays a leading role, with insufficient involvement of IS end users in the decision-making process. In this regard, the provision of all types of state support is supposed to be strictly targeted, with the specification of the purpose and principles of state aid for each region.

The emphasis in the implementation of ICT is placed on the collection of analytical information for making managerial and financial decisions that allow healthcare professionals to provide safe, highquality, timely and affordable medical services. In order to increase the share of GVA in healthcare, the creation of new medical institutions based on PPP is recommended. These steps, together with new approaches in the field of healthcare informatization, implemented in accordance with the development concept and state programs, allow us to modernize e-health in the coming years. Thus, the solution of these problems will be an important factor in improving the quality of life of citizens, economic growth and ultimately the long-term economic security of Kazakhstan.

\section{REFERENCES}

Official site of McKinsey \& Company (2011), A rising role for IT: McKinsey Global Survey results, Business Technology Office. McKinsey \& Company, December 2011, https://www.mckinsey.com/ business-functions/mckinsey-digital/our-insights/a-rising-role-for-it-mckinsey-global-survey-results

Akamatsu, K., (1962), "A Historical Pattern of Economic Growth in Developing Countries", Journal of Developing Economies, Vol. 1, No. 1, pp. 3-25.

Anselin, L., Vagra, A., Acs Z. (1997), "Local spillovers between university research and high technology innovations", Journal of Urban Economics Review, Vol. 76, pp. 984-1001.

Audretsch, D.B., Feldman, M.P. (1996), "R\&D spillovers and the geography of innovation and production", American Economic Review, Vol. 86, pp. 630-640.

Beardsley, Scott C., Enriquez, L., Bonini S., Sandoval, S., Brun, N. (2010), Fostering the Economic and Social Benefits of ICT, Global Information Technology Report 2009-2010: ICT for Sustainability. Palgrave Macmillan, Basingstoke, pp. 62-70.

Borkova, Y.A., Napolova, Y.A., Orlov, Y.R. (2019), "Problems of development and implementation of innovations in healthcare in Russia", Creative Economy. Vol. 13, No. 7, pp.1495-1502. doi: https://doi.org/10.18334/ce.13.7.40833

Burkov, S.S. (2013), "Information technologies and their role in the global innovation economy", The "MID" magazine (modernization, innovation, development), pp. 108-111.

Cardona, M., Kretschmer, T., Strobel, T. (2013), “ICT and Productivity: Conclusions from the Empirical Literature", Information Economics and Policy, No. 25(3), pp. 109-125.

de la Hoz-Rosales, B., Camacho-Ballesta, J. A., Tamayo-Torres, I. (2019), "Effects of innovative entrepreneurship and the information society on social progress: an international analysis", Entrepreneurship and Sustainability Issues, Vol. 7, No. 2, pp. 782-813,

Dudin, M.N., Lyasnikov, N.V., Lezina, M.L. (2018), Statistics: textbook and workshop for academic undergraduate, Urait Publishing House, Moscow (in Russian). 
Official site of Republican center for electronic health (2019), Healthcare Information Systems of the Ministry of Health of the Republic of Kazakhstan, Republican electronic health center, Ministry of health of the Republic of Kazakhstan, http://ezdrav.kz/posetitelyam/kratkoe-opisanieinformatsionnykh-sistem

International Telecommunication union. ICT Development Index 2017, https://www.itu.int/net4/ITUD/idi/2017/index.html\#idi2017economycard-tab\&KAZ

Korobkova, O.K. (2018), Theoretical aspects of the organizational and economic mechanism for the provision of health services in the digital economy: a monograph, FESMU Publishing House, Khabarovsk (in Russian).

Leonov, S.A. (2018), "Integration of healthcare, education and information and communication technologies in the framework of digitalization of domestic medicine", Actual problems of economics and management, Vol. 3, No. 19, pp. 35-39.

Lukashin, Y.P. (2003), Adaptive methods of short-term forecasting of time series, Finance and Statistics, Moscow (in Russian).

Marx, K., Engels, F. (1959), Toward a critique of political economy, K. Marx, F. Engels, Coll. ed., 2nd ed., State Political Publishing House, Moscow (in Russian).

Mochalyshkov V.N. (2012), Public private partnership.Domestic experience, global trends, development vector, Ekonomika, Moscow (in Russian).

Molinari, B., Torres, J.L. (2018), "Technological sources of economic growth in Europe and the U.S.", Technological and Economic Development of Economy, Vol. 24, No. 3, pp. 1178-1199. https://doi.org/10.3846/20294913.2017.1280557

Negroponte, N. (1995), Being Digital, N. Negroponte, Knopf, New York.

Nikonova, I.A., Yarygina, I.Z. (2018), Public-private partnership: foreign experience in project financing, Knorus, Moscow (in Russian).

OECD (2018), Oslo Manual: Guidelines for Collecting, Reporting and Using Data on Innovation, 4th Edition

Panshin, B. (2017), "Digital economy: features and development trends", Science and innovation, No. 3(157), pp. 18-20 (in Russian).

Qiang, C., Zhen-Wei, Rossotto, C.M., Kuniko, K. (2009), “Economic Impacts of Broadband”, Business, pp. 37-40.

Katz, R.L. (2015), The Economic Transformative Impact of Digital Technology, Institute for TeleInformation, Columbia University, https://unctad.org/meetings/en/Presentation/ecn162015 p09_Katz_en.pdf

Romer, P. (1986), “Increasing Returns and Long Run Growth”, Journal of Political Economy, Vol. 94, pp. 1002-1038.

Sachs, J.D. (2011), The End of Poverty: Economic Possibilities for Our Time, Publishing House of the Gaidar Institute, Moscow (in Russian).

Satpayeva, Z.T., Kalymbekova, Zh.K., (2019), "Innovative approaches to optimize the work of the state program in the light of digital transformations", Economics: Sstrategy and Practice, No. 2 (14), pp. 155-165 (in Russian).

Semenov, Y.A. (2017), "IT-economy in 2016 and after 10 years", Economic Strategies. No. 1 (143), pp. 126-135 (in Russian), http://www.inesnet.ru/wp-content/mag_archive/ 2017_01/es2017-01-126135_Yury_Semenov.pdf

The concept of development of e-health of the Republic of Kazakhstan for 2013-2020 (2013), Order of the Ministry of Healthcare of the Republic of Kazakhstan, No. 498.

Veselovsky, M.Y., Izmailova, M.A., Lobacheva, E.N., Pilipenko, P.P., Rybina, G.A. (2019), "Strategic management of innovation development: insights into a role of economic policy", Entrepreneurship and Sustainability Issues, Vol. 7, No. 2, pp. 1296-1307, https://doi.org/10.9770/jesi.2019.7.2(34)

Yemelina, N.K., Kozlova, N.G. (2015), Econometrics: Study guide. Karaganda, Karaganda Economic University of Kazpotrebsoyuz, Kazachstan.

Zolfani, S.H., Sedaghat, M., Zavadskas, E.K. (2012), "Performance evaluating of rural ICT centers (telecenters), applying fuzzy AHP, SAW-G and TOPSIS Grey, a case study in Iran”, Technological and Economic Development of Economy, Vol. 18, No. 2, pp. 364-387.

https://doi.org/10.3846/20294913.2012.685110 